\title{
Anti-Corruption in Microfinance and China's Reaction
}

\author{
Rongrong Zhou \\ Shandong High People's Court, Ji'nan, China \\ Email: mlbsabc@sina.com
}

How to cite this paper: Zhou, R.R. (2016) Anti-Corruption in Microfinance and China's Reaction. Open Journal of Social Sciences, 4, 130-139.

http://dx.doi.org/10.4236/jss.2016.410010

Received: October 3, 2016

Accepted: October 24, 2016

Published: October 27, 2016

Copyright $\odot 2016$ by author and Scientific Research Publishing Inc. This work is licensed under the Creative Commons Attribution International License (CC BY 4.0).

http://creativecommons.org/licenses/by/4.0/

\begin{abstract}
Microfinance offers poor people access to basic financial services such as loans, savings, money transfer services and micro insurance. Corruption happens in microfinance area and the FCPA applies to it. In China, micro finance and social enterprises have developed for year; however, the government corruption poses a chilling climate for the flourish of microfinance and the innovation of private capital. Chinese government took measures to fight corruption and via the government's action. Corruption problems became more tangible and more controllable.
\end{abstract}

\section{Keywords}

Microfinance, Corruption, FCPA, China

\section{Anti-Corruption in Microfinance}

Microfinance offers poor people access to basic financial services such as loans, savings, money transfer services and micro insurance. Microfinance primarily refers to the making of small loans to low-income individuals and the poor, to enable them to start or expand small businesses [1]. Currently, most microfinance loans are made through nonprofit microfinance institutions (MFIs) that receive donor money. After Muhammad Yunus invented the model of Grameen Bank, it became probably the most visible MFI. There are several others, including Accion International, FINCA, and the Women's World Bank. MFIs need regulation, and should face tough scrutiny. Whether MFIs commit to their ambition is the most important factor to be estimated.

It is significant to clarify the MFI's goals. The first and maybe the most important goal is alleviating poverty. The World Bank's latest data indicates that about 1.7 billion people are estimated to live in absolute poverty today. Microfinance is viewed as a very powerful approach to addressing worldwide poverty. Microfinance also serves as an 
excellent method to engage women in the global economy, with a particular focus on women who live in developing countries and have traditionally been limited the access to economic markets. Additionally, microfinance has been treated as an important financially investment tool that allows a financial, government or other institution to lend money to a new group of customers. There is a very high payback rate in MFI programs, with Grameen Bank quoting 98\%, which is impressive, and much higher than the usual loan repayment rate [2].

Distinguished from the traditional loan method, MFIs give the lender right not to submit substantial collaterals by use their social credit as collateral to lend. Thus MFIs do not require the standard "material" collateral. Instead, most MFIs require some form of what has been termed "social collateral" [3].

Corruption usually happens in business circumstances. However, in microfinance area, corruption is different from the traditional situations. Corruption may happen in the investor's level. Investors of the microfinance institutions may pay bribes to the local government and apply for policy support. Corruption may occur in the micro institution's level. Micro institutions pay the government bribes to acquire official facilitation. Corruption may also emerge in the micro entrepreneur's level. In most occasions, corruption is coercive by the government officials, often happens in the micro institution and micro entrepreneur's level. The government officials use their authority to ask for bribes and the parties involved in have no defense method. To prevent corruption for people doing business in foreign countries, US regulated FCPA. Whether FCPA applies to microfinance area, and what the regulatory boundary of donation is should be discussed.

\section{FCPA Applies to Microfinance}

For the application of FCPA in microfinance area, one important case is Testing Wynn's Charitable giving. In this case, The SEC sent a letter to Wynn Resorts last month asking about a $\$ 135$ million gift to the University of Macau Development Foundation. The SEC's inquiry followed allegations in a lawsuit filed in January by Wynn's biggest shareholder, Kazuo Okada. He called the \$135 million donation inappropriate because the final installment is due in ten years, when Wynn's Macau gaming license is set to expire. [4] The conclusion of this case is that the charitable contributions violate the FCPA, if they benefit government officials and are intended to obtain or retain business or gain an unfair advantage.

Another case is Schering-Plough, the maker of Afrin, Claritin, Coricidin, Cipro, and other drugs. In SEC's 2004 complaint, the Schering's Polish subsidiary donated to a charitable organization-Chudow Castle Foundation. The head was the director of Silesian Health Fund, which was a Polish governmental body funded the purchase of pharmaceuticals. Books and records didn't accurately record the payments and Schering-Plough's internal controls were inadequate to prevent or detect them. At a 2007 conference, Mark Mendelsohn, the head of the DOJ's FCPA unit, suggested charitable donations have to be considered on a case-by-case basis. 
If the government decision-maker holds a position at the charity, it is a red flag. It is neither an overall pattern nor an unusual target. The more important issue is whose idea was the donation. If government official grants the donation, then there is violation of the FCPA. The other important issue is that if it benefited a government official, whether the person hinted or begged for a payment to the charity. If the official simultaneously requires the payment, it is obviously violation of FCPA. Also, the other attractive benefit is tax deduction. In most countries, one important result of any gift to charity is tax relief. Whether to pursue a tax benefit is the warning sign. If there is tax pursue, there might be corruption and probably violates the FCPA.

One of the most famous opinion in microfinance involves in corruption is offered in FCPA Opinion Procedure Release of 2010. In this case, the requestor is a U.S. non-governmental organization and a "domestic concern" under the FCPA. The funding comes from grants and donations by governments, NGOs, public and private organizations, and individuals. The requestor has a wholly-owned, self-sufficient subsidiary organized as a limited liability company in "a Eurasian country". The Eurasian subsidiary wanted to donate $\$ 1.42$ million to a local microfinance institution through a grant. The requestor has been converting all of its local operations, including the Eurasian subsidiary, to commercial entities licensed as financial institutions. The conversion helps the local entities attract capital and offer new services such as savings accounts, microfinance, and remittances. The subsidiary' $\$ 1.42$ million grant to the local microfinance organization is required for the subsidiary's license conversion. The requestor investigated that one of the board members of the local microfinance institution and its parent "is a sitting government official in the Eurasian country and other board members are former government officials" [5].

The purpose of the proposed grant is to obtain or retain business. The DOJ reasoned that the Eurasian Subsidiary's nonprofit business is to be followed by for-profit business activity in the Eurasian country, and the proposed grant would be made as a condition precedent to obtaining a license to operate as a profit-making financial institution. Therefore the issue is whether the proposed grant would amount to the corrupt giving of anything of value to any officials of the Eurasian country in return for obtaining or retaining business.

In OPR 10-02, the DOJ announced that it would not take enforcement action against a microfinance institution ("MFI") for giving a grant-at the behest of a government agency-to a local microfinance institution whose board includes a sitting government official. The OPR 10-02 underscores: 1) the importance of thorough due diligence and strict controls in situations where a government directs a benefit to specified entities, and 2) the controls that the DOJ expects an entity to implement when providing a grant under such circumstances.

The opinion release also specified the three levels of due diligence that the US MFI had engaged in on the proposed locals MFIs which were listed as eligible to receive the funding. The DOJ noted that it "is satisfied, however, that the Requestor has done appropriate due diligence and that the controls that it plans to institute are sufficient to 
prevent FCPA violations."

There are several other FCPA Opinions related to donations. Procedure Release 95-01 is about a US based energy company planning to acquire and operate a plant in a country in South Asia that lacks modern medical facilities in the region where the plant is located. A modern medical complex is presently under construction near the requestor's future plant. Costs for the medical facility are projected to run to hundreds of millions of dollars. If the acquisition of the plant is completed, the requestor plans to donate $\$ 10$ million in a public ceremony to the medical facility for construction and equipment costs.

FCPA Opinion Procedure Release 1997-02 came from a U.S. utility constructing a plant in Asia. The requestor plans to donate $\$ 100,000$ to a proposed school construction project. The donation would be made directly to the government entity responsible for the construction and supply of the proposed elementary school. As the requestor's donation will be made directly to a government entity-and not to any foreign government official-the provisions of the FCPA do not appear to apply to this prospective transaction.

FCPA Opinion Procedure Release 06-01 comes from a company wanting to contribute money to a regional customs department or the Ministry of Finance in an African country as part of a pilot project to improve local enforcement of anti-counterfeiting laws. The Requestor seeks to make the monetary contribution to the Counterparty in order for the agency to fund incentive awards to local customs officials to improve local enforcement relating to seizures of counterfeit products bearing the trademarks of the Requestor and its competitors. These cases above further facilitate the analysis that microfinance institutions have to comply with the FCPA.

\section{Methods to Avoid Corruption in Microfinance}

There are methods to avoid corruption in microfinance area and get away from the FCPA. One of the most noticeable tools is disclosure. Different countries have different regimes in regulating disclosure, however the requirement is clear for the companies involved in the business operation to comply with disclosure. Specificity in disclosure requirements does not mean that highly detailed information should be disclosed. Not the more, the better. In most circumstances, disclosure of the various cost components and other terms of a financial product can be overwhelming and counterproductive to the objective of consumer comprehension [6].

\subsection{Disclosure to Consumers and the Public}

As the author Jennifer Chien analyzed, disclosure will be ineffective if important information is buried in loan agreements. A summary sheet is important to show the information. In Peru and Philippines, summary sheet and bank disclosure statement is accompanied with the credit contracts. She also suggested to use Standardized forms to facilitate consumers for understanding and comparing, "which can be further enhanced by incorporating such forms into consumer awareness and financial capability pro- 
grams to familiarize consumers with the format." She also observed that he disclosure regime in Ghana requires lenders to provide a standardized pre agreement statement to consumers. The pre agreement statement provided by regulation discloses APR, finance charges, filing fees, and late charges (with short plain-language explanations of each term) and includes checkboxes for key terms, such as credit insurance, variable interest, and prepayment penalties [7].

Besides in the individual level of disclosure, regimes can also work toward disclosure to the public. Though consumer comprehension is important, the objective of public disclosure is mainly for increasing market competition. As addressed by Jennifer, the public disclosure can be achieved from the demand side by providing consumers in the general market with sufficient information to comparison shop and "vote with their feet" (i.e., choose better products and providers) [8].

However in current situation, the power asymmetries have a great influence on transparency, even where disclosure regimes provide a full basis for consumer to make distinguished shopping. To increase market competition and enhance the process, regulators may improve other tools to facilitate the competition among providers, such as moral suasion by regulators and pressure by media. Donors and investors can also use their leverage and support to motivate MFIs to increase the transparency of their products, to increase competition on the supply side among providers, in order to have real impact on market competition.

Jennifer finally addressed that regulators should consider the intention of the micro institutions. "For example, to disclose information as broadly as possible to competing providers, media, and investors, focusing on key terms that are immediately comparable, such as APR and EIR, may be warranted."

\subsection{Comply with the Due Diligence Requirement}

In the Opinion Release 10-02, in addition to the specific discussion of the due diligence performed by the US MFI and noting the controls it had put in place after the funding was scheduled to be made the DOJ also listed several of the due diligence and/or controls that it had previously set forth in prior Opinion Releases relating to charitable donations. These included:

- certifications by the recipient that it will comply with the requirements of the FCPA;

- due diligence to confirm that none of the recipient's officers or directors are affiliated with the foreign government at issue;

- a requirement that the recipient provide audited financial statements;

- a written agreement with the recipient restricting the use of funds to humanitarian or charitable purposes only;

- steps to ensure that the funds were transferred to a valid bank account;

- confirmation that contemplated activities had occurred before funds were disbursed; and

- ongoing auditing and monitoring of the efficacy of the program.

Opinion Release 10-02 provides a wealth of information to the FCPA practitioner 
and compliance counsel. It gives specific guidance on the levels of due diligence that a US company should go through when investigating a charitable institution selected, or suggested by a foreign governmental official, to be the recipient of a company's charitable donations. Further it lists the controls that a US company can and should put in place, should it determine that a charitable donation is to be made. Opinion Release 10-02 gives significant guidance in pre-donation due diligence investigation, evaluation and post donation monitoring going forward to manage the process. Opinion Release 10-02 is also a very large and helpful educational tool in the FCPA compliance arena. [9] From my perspective, in order to comply with the disclosure and due diligence requirement, the microfinance institutions should set up a watchdog branch to evaluate and supervise the compliance procedures. They may also hire outside consultants as lawyers and accountants to better facilitate the compliance program.

\section{China's Reaction}

In China, social enterprise is emerging, so as microfinance institutions, especially in small cities and rural towns. As observed by Meng Zhao, the dynamics of the social enterprise sector cannot be understood without examining the cultural, political, and organizational forces that jointly define the meaning and form of Chinese social enterprises [10]. He addressed that the term social enterprise has taken on three forms in China, which are the social enterprise, the social startup, and the startup for public good. No matter what the title is, China's political and regulatory institutions are opening up new opportunities for the development of a grassroots nonprofit organization sector. Over the past 20 years, important government officials have taken proactive role in building a more favorable environment for nonprofits. However, even China's 12th five-year plan stresses innovation in the public administration system, the regulations of social enterprises and microfinance institutions are not clear. Chinese legal scholars and observers argue that the social reforms could turn into a new form of government administration rather than genuine empowerment for grassroots initiative. This triggers the issue of potential government corruption, which is an encumbrance for the blossom of microfinance.

Microfinance in China cannot flourish if Chinese government official continues to act in a current manner towards microfinance. The threat of inappropriate government actions is having a chilling effect on the micro small business people. Meng Zhao noted that the timing of seeking for more government support through legitimate cultural and organizational channels for bold social innovation is mature in China. However, if the corruption problem cannot be solved, there is no essential impact on the quality of regulation and the progressing of social enterprises.

As for anti-corruption striving, looking back upon China's overall economic growth over the past thirty years, one would assume that it would have little need for microfinance. Over this thirty-year span, it has emerged as an economic juggernaut, becoming the world's second largest economy, behind only the United States. China's gross domestic product (GDP) grew at an average of roughly nine percent over the last dec- 
ade, thereby surpassing the majority of countries in the world. This upward trend seems to be continuing as China's GDP grew over eleven percent in 2006. During this period of growth, China has slowly exchanged a planned economic approach, which essentially allows the government to dictate the economy, for a more market-oriented approach, which permits market forces to control the economy.

China's transformation has included: "the gradual liberalization of prices, fiscal decentralization, increased autonomy for state enterprises, the foundation of a diversified banking system, the development of stock markets, the rapid growth of the non-state sector, and the opening to foreign trade and investment." Many commentators believe that China's move toward a more market economy is the impetus behind its newly-minted economic success [11].

Chinese government is also establishing the credit market and regulating personal credits. Corruption may occur in the growth, scale, and the procedure turning into SMEs (Small and medium size of the enterprises). Corruption looms as one of the biggest political and economic challenges that faces China in the twenty-first century. Conservatively estimated at $13 \%-16 \%$ of China's GDP, corruption is a huge economic loss and a "social pollution", contributing to problems such as environmental degradation, social and political instability, and decreased credibility of government officials.

The Chinese Government has adopted a very strict attitude towards corruption and the Chinese criminal justice system (i.e. the police, prosecutors and judges) has been doing a very good job in preventing and punishing corruption [12]. Chinese people have wise reactions to corruption. Rooted in the traditional culture, people in China consider corruption from a "moral probity standard". They believe that officials should be as absolutely pure and clean as a perfect parent or God is, and corrupt behavior by officials betrays that beautiful image. Thus, what they expect of an anti-corruption policy or criminal justice is not only to eradicate corruption itself, but also to reform and maintain every official as something akin to a perfect parent or God. Such expectations are very idealistic and virtually unrealizable in the real world.

By contrast, Westerners consider corruption from a "free market standard". They believe that the government and market should be separated strictly and officials' corrupt behavior destroys such separation. Therefore they expect of an anti-corruption policy or criminal justice is merely to recover such separation. Moreover, the definition and scope of corruption also differ between Asia and the West.

Additionally, there is less access to governments by people in China. Even those who feel dissatisfied and wish to criticize the government are unable to do so without hesitation. They generally lack the chance to do so and must consciously choose to object or seek an opportunity to criticize. In recent years, policies have been promulgated to develop private capital, several spots have been selected as the testing area in the southeast part of China, such as Wenzhou in Zhejiang Province, and some cities in Guangzhou province. However, the private capitals develop and the private lending emerges with the corruption activities. One of the most significant case is the Wuying Death Penalty case in 2012, in which case the private loans and the corruption involved in this lending 
sent a 29-year-old girl, Wuying, to jail for 5 years. In 2012, there is trial for Wuying's death penalty, which attracts the whole country's concentration. Chinese government and the Supreme Court engaged in this case for the final decision. Under the supervision and the application of the recent policies, legal scholars and lawyers strived for the relief of Wuying. She was not sentenced to death. However, during this case the fighting between local governments (testing spots) and the central authority has become more complicate. The financial policies' relevance to the powerful government also emerges to the surface. Every Chinese people are under concern about the uncertainties of the financial climate, especially in the current policy environment.

Although the financial corruption in local areas and especially the testing spots are severe, the Chinese government has taken numerous measures to fight corruption. These measures include forbidding the government, police, and military to take part in business enterprises; implementing different accounting channels for revenues and for expenditures; and implementing a system of "accountant accreditation." Broadly speaking, this study puts forward six anti-corruption policy recommendations: 1) increasing transparency of government affairs; 2) encouraging citizen participation in government affairs; 3) strengthening the role of the deputy of the People's Congress; 4) ensuring an independent judiciary; 5) holding major government officials responsible for mistakes made under their purview; and 6) broadening the freedoms of the media. In addition, governmental interference in the economy and the discretionary power of government officials should be reduced.

\section{Government's Role in Fighting Corruption in Microfinance}

In the most recent Focus note of CGAP, the authors noted that the government should create the broader and interconnected ecosystem of market actors needed for "safe and efficient product delivery to the poor." [13] Under the observation of the authors, they addressed that the government's role mainly occurs in i) promoter of front- and back-end infrastructure, ii) rules maker with respect to that infrastructure and its contribution to responsible market development, and iii) driver of transaction. Each of these roles have significant impacts, and the application of these roles in the given jurisdiction will depend on country-specific factors, such as customer demand, market structure and maturity, government philosophy toward the market, and supervisory and other governmental capacity. The methods include founding or facilitating credit bureaus that "include data on small loans"; creating unique IDs; developing proportionate regulation and supervision of small depository institutions; enabling new branchless banking business models; defining the role of nonbank actors; encouraging interoperability of payment systems; and channeling G2P payments in a financially inclusive manner.

Existing bank branches are too expensive to construct in low-income areas, even when present, rarely offer affordable services. Governments have attempted to bridge the financial infrastructure gap in a variety of ways, focusing on both front-end infrastructure (the point of contact with customers, including ATMs, POS devices, and in- 
creasingly, local businesses serving as retail agents of financial services providers) and back-end infrastructure (the backbone needed for efficient financial services, including payment switches, credit bureaus, and collateral registries).

Governments should also be aware of the need for market-level infrastructure to serve financial inclusion. Governments are also involved in creating unique forms of ID that can enable access to the financial system. [14] The Chinese government should learn from the cutting-edge measures that taken by the US government to better operating the microfinance ecosystem, and that is a more friendly way to fight corruption.

\section{Conclusion}

Microfinance primarily refers to the making of small loans to low-income individuals and the poor, to enable them to start or expand small businesses. Corruption happens in microfinance area and the FCPA applies to it. Under the Opinion Release of 10-02, the DOJ indicates the standard of review for determining whether the government official in the micro institution has engaged in bribery. This opinion release also illustrates the due diligence requirements for micro finance participators to follow in the compliance with FCPA. In China, micro finance and social enterprises have developed for year; however the government corruption poses a chilling climate for the flourish of microfinance and the innovation of private capital. Chinese government took measures to fight corruption and via the government's action, corruption problems became more tangible and more controllable. In 2010, China released its first ever White Paper on the Nation's Anti-graft Efforts, expressing its resolve to strengthen the fight against corruption. The document, titled China's Efforts to Combat Corruption and Build a Clean Government, was issued by the Information Office of the State Council. Additionally, with effect from May 1, 2011, China was taking an extra-territorial long arm jurisdiction when it comes to the prosecution of bribery of foreign public officials. The new law captures Chinese nationals, companies and residents. An optimal belief is that those measures taken by the Chinese government are more favorable to private capital owners. Complied with the more transparent economic environment and a further sunlight government, microfinance in China will boost in the next few years and be more attractive to foreign investors. During these economic progresses, China's human rights protection will be further illustrated, the government will become more people-friendly and sunshine will be more gorgeous in China as well as its vision in the international arena.

\section{References}

[1] Schwarcz, S.L. Helping Microfinance Become Commercially Sustainable. 46 Gonz. L. Rev. 495.

[2] Farrer, R. (2008) Exploring the Human Rights Implications of Microfinance Initiatives. 36 International Journal Legal Info. 447.

[3] Rankin, K.N. (2002) Social Capital, Microfinance, and the Politics of Development. Feminist Economics, 8, 1-24. http://dx.doi.org/10.1080/13545700210125167 
[4] Testing Wynn's Charitable Giving. http://www.fcpablog.com/blog/2012/3/6/testing-wynns-charitable-giving.html

[5] Microfinance Meets the FCPA. http://www.fcpablog.com/blog/2010/7/23/microfinance-meets-the-fcpa.html

[6] Chien, J. (2012) Designing Disclosure Regimes for Responsible Financial Inclusion. CGAP Focus Note. No. 78.

[7] FSD-Kenya (2009) Definition of a Standard Measure for Consumer Interest Rates in Kenya: A Scoping Study. FSD-Kenya, Nairobi.

http://www.fsdkenya.org/pdf_documents/09-06-03_Definition_of_Std_Interest_Measures.pdf

[8] IDLO (2011) Consumer Protection and Microfinance: Country Reports. IDLO, Rome.

[9] Opinion Release 10-02 and Charitable Donations under the FCPA. http://www.corporatecomplianceinsights.com/opinion-release-10-02-and-charitable-donati ons-under-the-fcpa/

[10] Zhao, M. The Social Enterprise Emerges in China. Stanford Social Innovation Review, 10, 32.

[11] Wyatt Kendall, J. Microfinance in Rural China: Government Initiatives to Encourage Participation by Foreign and Domestic Financial Institutions. 12. N.C. Banking Inst. 375.

[12] Wang, Y.H. (2005) Corruption and Anti-Corruption Policy in Today's China. Hitotsubashi Journal of Law and Politics, 33, 1-5. http://hermes-ir.lib.hit-u.ac.jp/rs/han--dle/10086/8134

[13] Ehrbeck, T., Pickens, M. and Tarazi, M. (2012) Financially Inclusive Ecosystems: The Roles of Government Today. CGAP Focus Note No.76.

[14] From May 1st New China Anti-Corruption Laws Follow Long Arm Jurisdiction Trend. http://thebriberyact.com/2011/05/30/from-may-1st-new-china-anti-corruption-laws-follow -long-arm-jurisdiction-trend/

Submit or recommend next manuscript to SCIRP and we will provide best service for you:

Accepting pre-submission inquiries through Email, Facebook, LinkedIn, Twitter, etc. A wide selection of journals (inclusive of 9 subjects, more than 200 journals)

Providing 24-hour high-quality service

User-friendly online submission system

Fair and swift peer-review system

Efficient typesetting and proofreading procedure

Display of the result of downloads and visits, as well as the number of cited articles

Maximum dissemination of your research work

Submit your manuscript at: http://papersubmission.scirp.org/

Or contact jss@scirp.org 